\title{
Dental Pulp Stem Cells, a New Era in Regenerative Medicine: A Literature Review
}

\author{
Manar Aljamie ${ }^{*}$, Lujain Alessa1, Rawan Noah'1, Lubna Elsayed ${ }^{2}$ \\ ${ }^{1}$ College of Dentistry, Princess Nourah Bint Abdulrahman University, Riyadh, Kingdom of Saudi Arabia \\ ${ }^{2}$ Basic Dental Sciences Department, College of Dentistry, Princess Nourah Bint Abdulrahman University, Riyadh, \\ Kingdom of Saudi Arabia \\ Email: "ManarAljamie@hotmail.com, Lujain.Alissa@gmail.com,RawanNoah@gmail.com, \\ Lkelsayed@pnu.edu.sa
}

Received 30 April 2016; accepted 4 June 2016; published 7 June 2016

Copyright (C) 2016 by authors and Scientific Research Publishing Inc.

This work is licensed under the Creative Commons Attribution International License (CC BY).

http://creativecommons.org/licenses/by/4.0/

(c) (i) Open Access

\begin{abstract}
Objectives: The aim of this review is to explain the role of Dental Pulp Stem Cells (DPSCs) in repairing or regenerating damaged tissue/organs for both systemic and oral diseases and, in addition, review the differentiation, isolation of dental pulp stem cells and their applications in regenerative medicine. Materials and Methods: An electronic search was done using Cohchrane, PubMed and Google Scholar. Out of $\mathbf{3 1 0}$ articles, only 25 articles have been selected to be included in this review because it is directly related to the topic and they are matching the inclusion criteria of this review: "Language: English" and "Year: 2006-2016". Results: DPSCs have been widely used as a mesenchymal stem cells source due to easy accessibility and less invasive harvesting. DPSCs could be used for pulpal regeneration, tooth reconstruction, endocrinology, neurology, angiogenesis and vasculogenises. The most common application of DPSCs in the dental field is pulp regeneration. Conclusion: Stem cell-based therapy holds a great promise to solve health problems from both systemic and oral diseases. Studying in DPSCs grows rapidly; however, there are still questionable issues needed to be optimized and answered such as the variable biological capacity of DPSCs.
\end{abstract}

\section{Keywords}

Stem Cells, Dental Pulp Stem Cells, Regenerative Medicine

\section{Introduction}

The stem cells field represents an area of particular interest for scientific research. Stem cells are undifferen-

"Corresponding author.

How to cite this paper: Aljamie, M., Alessa, L., Noah, R. and Elsayed, L. (2016) Dental Pulp Stem Cells, a New Era in Regenerative Medicine: A Literature Review. Open Journal of Stomatology, 6, 155-163.

http://dx.doi.org/10.4236/ojst.2016.66020 
tiated cells having a property of self-renewal and further differentiate into various types of specialized cells as shown in Table 1 [1] [2]. These stem cells can be found in a number of adult tissues including skin, adipose tissues [3], peripheral blood [4] [5], bone marrow, pancreas, intestine, brain, hair follicles, as well as in the dental pulp cells [2] [6]. Studies have shown that the dental pulp tissue can also be used to derive Mesenchymal Stem Cells (MSCs) when tissue is grown in culture [2].

The results so far obtained give good expectations for the use of stem cells in clinical trials. Stem cell research has expanded well due to their usefulness in regenerative therapies for improving the life of patients suffering from various genetical and neurological diseases [2]. New therapeutic strategies have been made possible thanks to great advancements in stem cell biology, with the aim of regenerating tissues injured by disease [7]. Based on the ability of stem cells to rescue and/or repair injured tissue and partially restore organ function, multiple types of stem/progenitor cells have been speculated [7].

Tissue engineering is an interdisciplinary field that connects various scientific aspects from engineering, materials science, biology, and medicine [8].

The aim of this review is mainly highlighting the importance of DPSCs, differentiation and their applications in regenerative medicine.

\section{Materials and Methods}

An electronic search was done using the following databases: PubMed, Cohchrane and Google Scholar. The online searching was conducted following these keywords: "Stem cells" or "Dental pulp stem cells" or "Regenerative medicine" out of 310 articles, only 25 articles have been selected to be included in this review because it is directly related to the topic and also these articles have been chosen based on the inclusion criteria: "Language: English" and "Year: 2006-2016". A table was constructed to express the details of the searched articles in the appendix part of this paper (Scheme 1, Table A1).

\section{MSC}

MSCs were first described in 1976 by Friedenstein and colleagues and are more recently defined by The International Society of Cellular Therapy based on an important cellular property which is the ability of the cell to differentiate into osteocytes, adipocytes, and chondrocyte [9]. MSCs constitutes a heterogeneous population of cells and there are two main types of stem cells, embryonic and non-embryonic. Embryonic Stem Cells (ESCs) are derived from the inner cell mass of the blastocyst and can differentiate into cells of all three germ layers [2] [10]. On the other hand, non-embryonic stem cells, mostly adult stem cells, are already somewhat specialized and have limited differentiation potential [10]. They can be isolated from various tissues and are currently the most commonly used seed cells in regenerative medicine [10].

MSC are generated through enforced expression of defined transcription factors, which reset the fate of somatic cells to an embryonic stem-cell-like state [10]. MSCs have a rapid proliferation ability, achieving a thousand fold expansion of cell number in a two- to three-week period. However, inappropriate expansion may

Table 1. Normal differentiation pathways of adult stem cells from various tissues and cells.

\begin{tabular}{|c|c|c|}
\hline Stem cell & Source & Type of cells produced \\
\hline Hematopoietic & $\begin{array}{l}\text { All types of blood } \\
\text { cells }\end{array}$ & $\begin{array}{l}\text { Red blood cells, B lymphocytes, T lymphocytes, natural killer cells, neutrophils, basophils, } \\
\text { eosinophils, monocytes, macrophages and platelets. }\end{array}$ \\
\hline $\begin{array}{l}\text { Bone marrow } \\
\text { Stromal cells } \\
\text { (mesenchymal) }\end{array}$ & Connective tissues & Tendons, osteocytes (bone cells), adipocytes (fat cells), chondrocytes (cartilage cells) \\
\hline Neural & $\begin{array}{l}\text { Parts of the nervous } \\
\text { system }\end{array}$ & Neurons, astrocytes and oligodendrocytes \\
\hline Epithelial & $\begin{array}{l}\text { Lining of the } \\
\text { digestive tract }\end{array}$ & Absorptive cells, goblet cells, paneth cells and endocrine cells \\
\hline Epidermal & $\begin{array}{l}\text { Basal layer of } \\
\text { epidermis }\end{array}$ & Keratinocytes and dermal cells \\
\hline Follicular & Base of hair follicles & Hair follicles and epidermis \\
\hline Hepatic & Liver & Hepatocyte cells \\
\hline
\end{tabular}




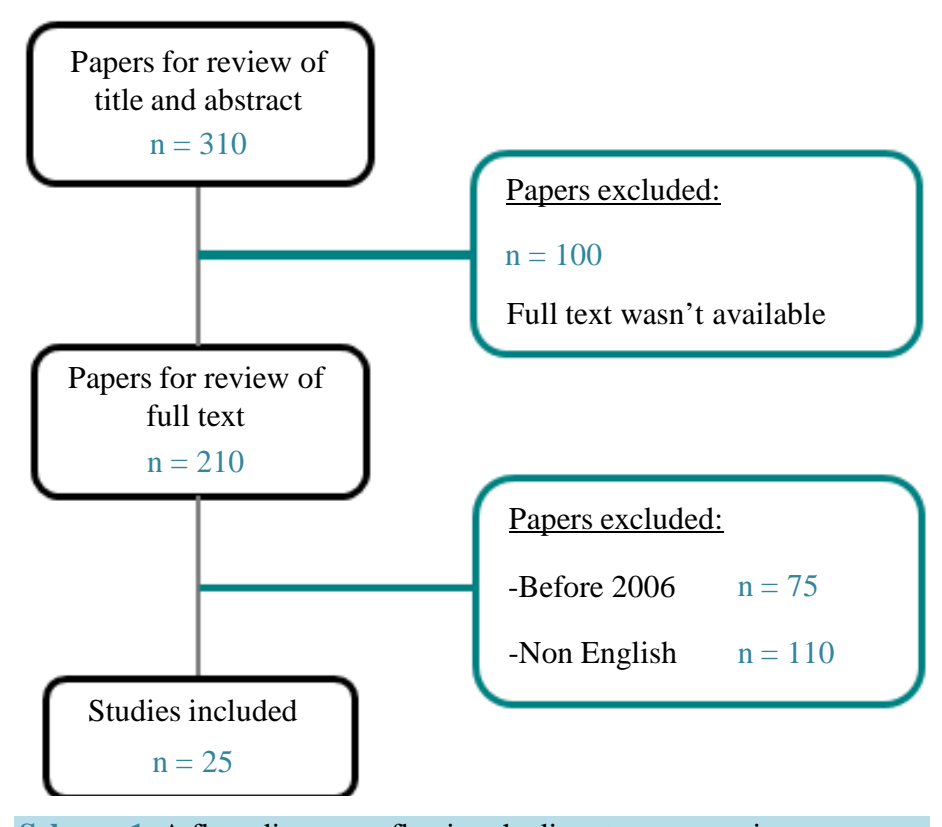

reduce the quality of MSCs [9]. It is known that extensive in vitro culture induces cellular senescence that is associated with growth arrest and apoptosis. In addition, particular therapeutic properties of MSCs may be lost during prolonged culture [9].

Embryonic stem cells and non-embryonic stem cells have all been explored as potential therapeutic strategies for a number of diseases [10]. One type of adult stem cells, mesenchymal stem cells, has generated a great amount of interest in the field of regenerative medicine due to their unique biological properties [10].

\section{DPSC}

Dental pulp is a soft connective tissue within the dental crown, it is an interesting source of adult stem cells because of the large amount of cells present and it is considered to be a non invasive process of extraction of MSCs from dental pulp tissue compared to other adult tissue sources [2] [11]. Dental pulp tissue is thought to be derived from migrating neural crest cells during development [2] [11].

Dental pulp contains mesenchymal stem cells defined as Dental Pulp Stem Cells (DPSCs). DPSCs are obtained from human permanent and primary teeth, human wisdom teeth, human exfoliated deciduous teeth (SHEDs), and apical papilla [2] [11]. Other sources of dental stem cells are the periodontal ligament, which houses Periodontal Ligament Stem Cells (PDLSCs), and the dental follicle, which contains Dental Follicle Progenitor Cells (DFPCs) [7]. During the development of teeth, there is an interaction between epithelial cells of dental pulp which lead to the differentiation of ameloblasts and odontoblasts, resulting into deposition of specialized mineralized matrices, i.e., enamel and dentin respectively. The inner area of dental pulp chamber contains a highly proliferative stem/progenitor cells possessing a self-renewal and differentiation properties [2]. It has been shown that after teeth eruption, there is an induction of reparative dentin formation which protects dental pulp from further degradation. DPSCs or stem cells from human exfoliated deciduous teeth (SHED) cells require a longer time for initial colony formation than other somatic cells. Third molar teeth derived cells differentiate into odontoblasts and secrete $3 \mathrm{D}$ like crystal structure in vitro. Figure 1 shows calcium phosphate crystals secreted from DPSCs cells in a culture experiment [2]. It has been shown that DPSCs can be differentiated by modulation with growth factors, transcriptional factors, extracellular matrix proteins and receptor molecules into different cell types include odontoblast, osteoblast, chondrocyte, cardiomyocytes, neuron cells, adipocyte, corneal epithelial cell, melanoma cell and insulin secreting Beta cells [2]. DPSCs usually remain quiescent when they are within the dental pulps, but respond quickly after injury. Theses DPSCs have a high proliferative capacity and immediately differentiate into odontoblasts, osteoblasts, and chondrocytes to produce dentin, bone, and cartilage tissues respectively for this repair process [2]. 

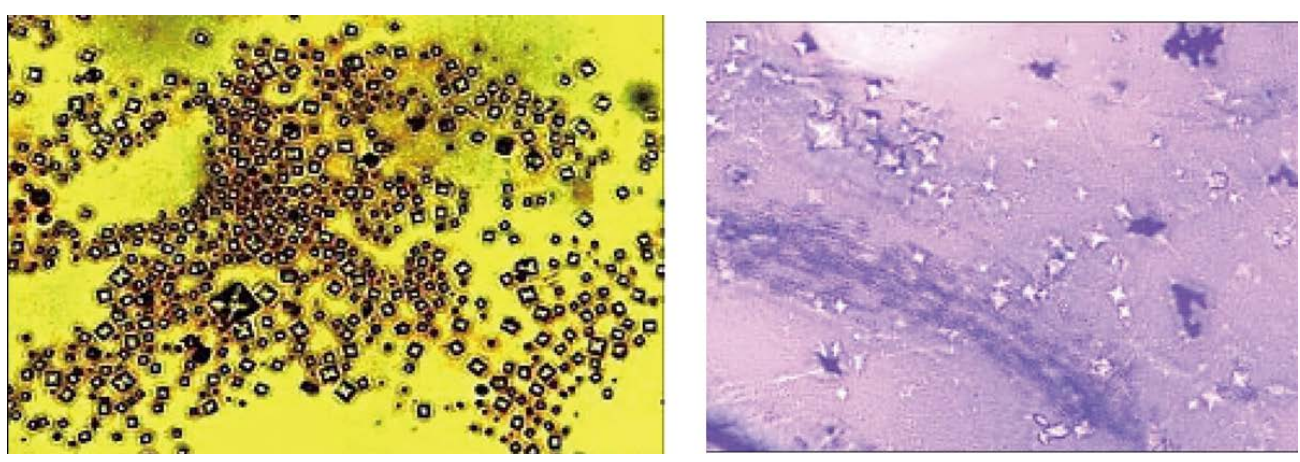

Figure 1. Calcium phosphate crystals secreted by dental pulp stem cells stained using silver and Giemsa in culture [2].

\section{Isolation of DPSC}

Isolation of stem cells from human dental pulp could be done by several methods based on many experiments and investigations. Some of these methods explained in this review.

1) Raoof et al. 2014 [12]

Method of isolation: 3 different methods for isolation of DPSCs from dental pulp tissue:

a) Dental pulp tissue is digested with collagenase or dispase enzyme and isolated trypsinised cells are plated in culture dishes;

b) They have explanted undigested dental pulp small tissue pieces directly to petridishes; and

c) Dental pulp tissues are initially trypsinised and then small tissue pieces are explanted to petridishes for their outgrowth.

They have grown these cultures in Minimum Essential Medium (MEM) supplemented with 20\% Fetal Bovine Serum (FBS) at $37^{\circ} \mathrm{C}$ with $5 \% \mathrm{CO}_{2}$ and $90 \%$ humidity in $\mathrm{CO}_{2}$ incubator.

Result: The third method gives better cell outgrowth with achieving confluency at $60 \%$ within 2 days of culture.

They have recommended the third method for isolation of DPSCs from dental pulp.

2) Lindemann et al. 2014 [13]

Method of isolation: They have isolated dental pulp cells from 7 days old non-cryopreserved and cryopreserved human deciduous teeth and culture them simultaneously.

Result: No change in differentiating and immunophenotype properties of both these cells. But there is a change in the morphology, proliferative capacity of cryopreserved cells than non-cryopreserved cells.

3) Lin et al. 2014 [14]

Method of isolation: Human DPSCs isolated from extracted teeth are frozen and then stored at $-196^{\circ} \mathrm{C}$ for 24

h. During freezing, the cells are suspended in freezing media containing 10\% dimethylsulfoxide (DMSO).

Result: when the freezing medium is DMSO free, the survival rates of revived DPSCs increase by 2 to 2.5 folds.

4) Gioventù et al. 2012 [15]

Method of isolation: They have studied 4 human deciduous whole teeth, cryopreserved by making microchannels into the tooth with the help of laser beam and then preserve these cells at $-80^{\circ} \mathrm{C}$.

Result: This method saves a time in isolating DPSCs before cryopreservation and thus reduces the initial costs and workload of tooth banking. The DPSCs cells isolated by this method have shown normal morphology, cell viability and proliferation rate as well as maintain normal mesenchymal phenotype, similar to those of cells isolated from fresh non-cryopreserved teeth.

They have further shown that DPSCs isolated without laser piercing have significant loss of cell viability and proliferation rate as compared to teeth cryopreserved by leaser piercing.

\section{Differentiation of DPSC}

DPSC represent a rapidly proliferating cell population that readily differentiates into the osteoblastic, neural, myocytic, and hepatocytic lineages. This multi-lineage capacity of these DPSC suggests that they may have a 
more broad therapeutic application than lineage-restricted adult stem cell populations [16].

DPSCs differentiate into different kinds of cells and tissues and their multi-potency has been compared to those of Bone Marrow Stem Cells (BMSCs). It has been demonstrated that proliferation, availability, and cell number of DPSCs are greater than BMSC [5].

Stem Cells from Apical Papilla (SCAP) are the cells which are found at the tooth root apex. They have higher proliferation rates as well as have a differentiation property in vitro similar to DPSCs. They are capable of differentiating into odontoblast cells and produce dentin in vivo [17]. Due to their higher proliferative potential, SCAPs are also suitable for cell-based therapy for formation of apex roots [17].

Human periodontal ligament stem cells (PDLSCs) can differentiate into cementoblast-like cells. They also have a capacity to form connective tissue which is rich in collagen I fibers [17].

\section{Differentiation Markers}

LIF gene is called as Leukemia Inhibitory Factor and involved in the induction of hematopoietic differentiation in normal and myeloid leukemia cells. It plays a role in immune tolerance at the maternal fetal interface [2]. LIF derives its name from its ability to induce the terminal differentiation of myeloid leukemic cells [2]. The other differentiating marker is a Keratin18. It is a Keratin Associated-Protein (KAP) which forms a matrix of keratin intermediate filaments of cell cytoskeleton structure. Keratin 8, Keratin 18, and keratin 19 are used as a marker for epithelial cells and differentiate from hematopoietic cells [18].

\section{Application of DPSC}

Suitable stem cells for tissue engineering should be able to differentiate into the target tissue/organ and should be easily collected and prepared to provide a further benefit to ensure the safety of the patient. DPSCs hold great clinical potential due to their differentiation capacity and easy accessibility.

1) De novo pulp regeneration [19]

When the entire pulp tissue is lost, regeneration requires the de novo creation of pulp. In order to create functional pulp for clinical application, several issues must be considered: first, regenerated pulp tissue must be vascularized, even through the blood supply occurs only from the apical foramen; second, newly differentiated odontoblasts should form on the existing dentinal wall of the root canal space; and finally, new dentin must be produced by the differentiated odontoblasts on the existing dentin.

2) Tooth reconstruction [20]

As our understanding of tooth formation, the stem cell niche and regenerative mechanisms extends, it may be possible to generate a method to biologically replace lost teeth. A functional biological replacement tooth must include generation of a root and periodontal ligament with nerve and blood supplies. The crown, although the most visible part of the tooth, is actually less important in terms of regeneration, since replacement of crowns with synthetic functioning options is possible.

3) Neurology [21]

Dental pulp cells have also been proposed as a treatment for peripheral nerve injury. Initially, dental pulp cells were transplanted into collagen gels and infused within a silicon tube, which was positioned within a $7 \mathrm{~mm}$ gap in the buccal branch of rat facial nerve. The dental pulp cells formed blood vessels and myelinating tissue and contributed to the promotion of normal nerve regeneration. In a subsequent study, a degradable poly (dl-lactideco-glycolide) (PLGA) tube was developed to avoid the need for a potential second operation to remove the silicon tube.

4) Angiogenesis and vasculogenesis [22]

Stem cells and endothelial progenitor cells (EPCs) can be utilized to stimulate vasculogenesis as a potential treatment for ischaemic disease. Correspondingly therapeutic benefits of injection of bone marrow-or adiposederived MSCs after myocardial infarction (MI) and other heart diseases have also been reported. Several studies have investigated the potential of DPSCs and sub-fractions of DPSCs as modes of treatment for MI and ischaemia.

5) Endocrinology [23]-[25]

Cell therapy treatments for liver disease require effective stem-cell derived hepatocytes. DPSCs have been differentiated to produce Hepatocyte-Like Cells (HLCs) with acquired hepatocyte functions, such as glycogen storage and urea production. Recently, hepatic differentiation of hDPSCs was undertaken using cryopreserved 
dental pulp tissue from teeth with disease. Differentiated cells possessed a polygonal shape and normal karyotype and expressed hepatic metabolic function genes and liver-specific genes. Glycogen storage and urea production results indicated that the differentiated hDPSCs were functionally close to normal hepatocyte-like cells (HLCs). Although research into hepatic differentiation of DPSCs is at an early stage, the use of cryopreserved tissue to generate HLCs provides a promising alternative for the treatment of liver diseases.

\section{Conclusions}

Stem cell-based therapy holds a great promise to solve health problems from both systemic and oral diseases. The identification of a good stem cell source is a major key for a success in tissue regeneration. Although stem cells can be isolated from a variety of tissues at various developmental stages with different stem cell capacities, human Dental Pulp Stem Cells (DPSCs), dental tissue-derived adult stem cells, have been widely studied due to their great clinical potential as a mesenchymal stem cell source, easy accessibility and less invasive harvesting.

Recently, the applications of DPSC in the dental field have been widely used. Most common application is pulp regeneration since pulpal pathology is commonly seen in the dental clinics; in addition pulp regeneration is extremely needed to preserve the infected pulp and protect the tooth from being non-vital.

Since the first discovery of DPSCs in 2000, studying in DPSCs grows rapidly. Nevertheless, there are still questionable issues needed to be optimized and answered such as the variable biological capacity of DPSCs.

\section{References}

[1] Potdar, P.D. and Deshpande, S. (2013) Mesenchymal Stem Cell Transplantation: New, Avenues for Stem Cell Therapies. Journal of Transplantation Technologies \& Research, 3, 1-16.

[2] Potdar, P.D. and Jethmalani, Y.D. (2015) Human Dental Pulp Stem Cells: Applications in Future Regenerative Medicine. World Journal of Stem Cells, 7, 839-851. http://dx.doi.org/10.4252/wjsc.v7.i5.839

[3] Potdar, P. and Sutar, J. (2010) Establishment and Molecular Characterization of Mesenchymal Stem Cell Lines Derived from Human Visceral \& Subcutaneous Adipose Tissues. Journal of Stem Cells and Regenerative Medicine, 6, 26-35.

[4] Potdar, P.D. and D’souza, S.B. (2011) Isolation of Oct4+, Nanog+ and SOX2- Mesenchymal Cells from Peripheral Blood of a Diabetes Mellitus Patient. Human Cell, 24, 51-55. http://dx.doi.org/10.1007/s13577-011-0011-6

[5] Potdar, P. and Subedi, R. (2011) Defining Molecular Phenotypes of Mesenchymal and Hematopoietic Stem Cells Derived from Peripheral Blood of Acute Lymphocytic Leukemia Patients for Regenerative Stem Cell Therapy. Journal of Stem Cells and Regenerative Medicine, 7, 29-40.

[6] Potdar, P.D. and Chougule, S. (2011) Establishment and Molecular Characterization of Breast Cancer Mesenchymal Stem Cell Line Derived from Human Non-Metastasis Breast Cancer Tumor. Stem Cell Discovery, 1, 21-28. http://dx.doi.org/10.4236/scd.2011.12003

[7] La Noce, M., Paino, F., et al. (2014) Dental Pulp Stem Cells: State of the Art and Suggestions for a True Translation of Research into Therapy. Journal of Dentistry, 42, 761-768. http://dx.doi.org/10.1016/j.jdent.2014.02.018

[8] Kim, B.-C., Bae, H., et al. (2012) Osteoblastic/Cementoblastic and Neural Differentiation of Dental Stem Cells and Their Applications to Tissue Engineering and Regenerative Medicine. Tissue Engineering: Part B, 18, 235-244. http://dx.doi.org/10.1089/ten.teb.2011.0642

[9] Ikebe, C. and Suzuki, K. (2014) Mesenchymal Stem Cells for Regenerative Therapy: Optimization of Cell Preparation Protocols. BioMed Research International, 2014, Article ID: 951512. http://dx.doi.org/10.1155/2014/951512

[10] Wang, S.H., Qu, X.B., et al. (2012) Clinical Applications of Mesenchymal Stem Cells. Journal of Hematology \& Oncology, 5, 19. http://dx.doi.org/10.1186/1756-8722-5-19

[11] Arthur, A., Rychkov, G., et al. (2008) Adult Human Dental Pulp Stem Cells Differentiate toward Functionally Active Neurons under Appropriate Environmental Cues. Stem Cells, 26, 1787-1795. http://dx.doi.org/10.1634/stemcells.2007-0979

[12] Raoof, M., Yaghoobi, M.M., et al. (2014) A Modified Efficient Method for Dental Pulp Stem Cell Isolation. Dental Research Journal (Isfahan), 11, 244-250.

[13] Lindemann, D., Werle, S.B., Steffens, D., Garcia-Godoy, F., Pranke, P. and Casagrande, L. (2014) Effects of Cryopreservation on the Characteristics of Dental Pulp Stem Cells of Intact Deciduous Teeth. Archives of Oral Biology, 59, 970-976. http://dx.doi.org/10.1016/j.archoralbio.2014.04.008

[14] Lin, S.L., Chang, W.J., et al. (2015) Static Magnetic Field Increases Survival Rate of Dental Pulp Stem Cells during DMSO-Free Cryopreservation. Electromagnetic Biology and Medicine, 34, 302-308. 
http://dx.doi.org/10.3109/15368378.2014.919588

[15] Gioventu, S., Andriolo, G., et al. (2012) A Novel Method for Banking Dental Pulp Stem Cells. Transfusion and Apheresis Science, 47, 199-206. http://dx.doi.org/10.1016/j.transci.2012.06.005

[16] Ferro, F., Spelat, R. and Baheney, C.S. (2014) Dental Pulp Stem Cell (DPSC) Isolation, Characterization, and Differentiation. In: Kioussi, C., Ed., Stem Cells and Tissue Repair, Methods and Protocols, Springer, New York, 91-115. http://dx.doi.org/10.1007/978-1-4939-1435-7_8

[17] Shaikh, R.A.R. (2013) Therapeutic Potential of Stem Cells in Regenerative Dentistry; a Review of Literature. International Dental Journal of Student's Research, 1.

[18] Doherty, G.J. and McMahon, H.T. (2008) Mediation, Modulation, and Consequences of Membrane-Cytoskeleton Interactions. Annual Review of Biophysics, 37, 65-95.

[19] Huang, G.T. (2011) Dental Pulp and Dentin Tissue Engineering and Regeneration: Advancement and Challenge. Frontiers in Bioscience (Elite Edition), 3, 788-800.

[20] Volponi, A.A., Pang, Y. and Sharpe, P.T. (2010) Stem Cell-Based Biological Tooth Repair and Regeneration. Trends in Cell Biology, 20, 715-722. http://dx.doi.org/10.1016/j.tcb.2010.09.012

[21] Ellis, K.M., O’Carroll, D.C., Lewis, M.D., Rychkov, G.Y. and Koblar, S.A. (2014) Neurogenic Potential of Dental Pulp Stem Cells Isolated from Murine Incisors. Stem Cell Research \& Therapy, 5, 30.

[22] Iohara, K., Zheng, L., et al. (2008) A Novel Stem Cell Source for Vasculogenesis in Ischemia: Subfraction of Side Population Cells from Dental Pulp. STEM CELLS, 26, 2408-2418. http://dx.doi.org/10.1634/stemcells.2008-0393

[23] Ishkitiev, N., Yaegaki, K., et al. (2012) High-Purity Hepatic Lineage Differentiated from Dental Pulp Stem Cells in Serum-Free Medium. Journal of Endodontics, 38, 475-480.

[24] Patil, R., Kumar, B.M., et al. (2014) Multilineage Potential and Proteomic Profiling of Human Dental Stem Cells Derived from a Single Donor. Experimental Cell Research, 320, 92-107. http://dx.doi.org/10.1016/j.yexcr.2013.10.005

[25] Chen, Y.K., Huang, A.H., Chan, A.W.S. and Lin, L.M. (2013) Human Dental Pulp Stem Cells Derived from Cryopreserved Dental Pulp Tissues of Vital Extracted Teeth with Disease Demonstrate Hepatic-Like Differentiation. Journal of Tissue Engineering and Regenerative Medicine. http://dx.doi.org/10.1002/term.1763 


\section{Appendix}

Table A1. Details of the searched articles (narrative review).

\begin{tabular}{|c|c|c|c|c|}
\hline No. & Author/year & Language & $\begin{array}{l}\text { Type of } \\
\text { study }\end{array}$ & Result/outcome \\
\hline 1. & $\begin{array}{l}\text { Potdar PD, } \\
\text { Deshpande S. } \\
\text { (2013) }\end{array}$ & English & $\begin{array}{l}\text { Review of } \\
\text { article }\end{array}$ & $\begin{array}{l}\text { MSCs transplantation promises to transform the traditional use of embryonic stem } \\
\text { cells to modern therapeutic applications. }\end{array}$ \\
\hline 2. & $\begin{array}{l}\text { Pravin D Potdar, } \\
\text { Yogita D } \\
\text { Jethmalani. (2015) }\end{array}$ & English & $\begin{array}{l}\text { Review of } \\
\text { article }\end{array}$ & $\begin{array}{l}\text { Advancement in stem cell and scaffold technology, damaged or lost teeth can be } \\
\text { replaced by the use of regenerative therapies. }\end{array}$ \\
\hline 3. & $\begin{array}{l}\text { Potdar P, Sutar J. } \\
\text { (2010) }\end{array}$ & English & $\begin{array}{l}\text { Laboratory } \\
\text { study }\end{array}$ & $\begin{array}{l}\text { It has been shown for the first time that both VAST and SCAT cell types differ in } \\
\text { their characteristics by morphology as well as at molecular level, indicating that } \\
\text { both cell types play different roles in the adipogenesis process. }\end{array}$ \\
\hline 4. & $\begin{array}{l}\text { Potdar PD, D’souza } \\
\text { SB. (2011) }\end{array}$ & English & $\begin{array}{l}\text { Review of } \\
\text { article }\end{array}$ & $\begin{array}{l}\text { Peripheral blood can be used as a source of MCs from diabetes mellitus patients } \\
\text { for use in future regenerative stem cell therapy and that this particular model } \\
\text { system may be useful to study the mechanism of diabetes mellitus involving } \\
\text { downregulation of the SOX2 cascade. }\end{array}$ \\
\hline 5. & $\begin{array}{l}\text { Potdar P, Subedi R. } \\
\text { (2011) }\end{array}$ & English & $\begin{array}{l}\text { Laboratory } \\
\text { study }\end{array}$ & $\begin{array}{l}\text { Isolated MSCs and HSCs can be used as a model system to study the mechanism } \\
\text { of leukemia at stem cell level and their use in stem cell regeneration therapy for } \\
\text { Acute Lymphocytic Leukemia. }\end{array}$ \\
\hline 6. & $\begin{array}{l}\text { Potdar PD, } \\
\text { Chougule S. (2011) }\end{array}$ & English & $\begin{array}{l}\text { Laboratory } \\
\text { study }\end{array}$ & $\begin{array}{l}\text { hBCMSCs cell line may represent a suitable in vitro model to study the mechanism } \\
\text { of breast cancer which further leads to an identification of molecular targets for } \\
\text { future breast cancer targeted therapy. }\end{array}$ \\
\hline 7. & $\begin{array}{l}\text { Marcella La Noce } \\
\text { a, Francesca Paino } \\
\text { a, et al. (2014) }\end{array}$ & English & $\begin{array}{l}\text { Review of } \\
\text { article }\end{array}$ & $\begin{array}{l}\text { DPSCs are mesenchymal stem cells expressing mesenchymal, haematopoietic } \\
\text { and stemness markers. These cells: 1) differentiate into different tissues of } \\
\text { mesenchymal origin, but also into functional melanocytes and neurons; 2) maintain } \\
\text { their characteristics after cryopreservation for years if stored as selected stem cells } \\
\text { and not as part of whole pulp; 3) differentiate into bone-like tissues in animal } \\
\text { models when loaded on scaffolds; 4) regenerate bone in human grafts; 5) are an } \\
\text { excellent model for the study of bone formation on substrates appropriate for } \\
\text { clinical bone remodelling applications. }\end{array}$ \\
\hline 8. & $\begin{array}{l}\text { Byung-Chul Kim, } \\
\text { Hojae Bae, et al. } \\
\text { (2012) }\end{array}$ & English & $\begin{array}{l}\text { Review of } \\
\text { article }\end{array}$ & $\begin{array}{l}\text { The multilineage differentiation capacity, especially into osteoblastic/ } \\
\text { cementoblastic lineage and neural lineages of dental stem cells such as dental pulp } \\
\text { stem cells (DPSC), dental follicle stem cells (DFSC), periodontal ligament stem } \\
\text { cells (PDLSC), and dental papilla stem cells (DPPSC). }\end{array}$ \\
\hline 9. & $\begin{array}{l}\text { Chiho Ikebe and } \\
\text { Ken Suzuki. (2014) }\end{array}$ & English & $\begin{array}{l}\text { Review of } \\
\text { article }\end{array}$ & $\begin{array}{l}\text { Feasibility and safety of the employment of BM-derived MSCs for a variety of } \\
\text { therapeutic indications including regenerative therapy. }\end{array}$ \\
\hline 10. & $\begin{array}{l}\text { Shihua Wang, } \\
\text { Xuebin Qu, et al. } \\
\text { (2012) }\end{array}$ & English & $\begin{array}{l}\text { Review of } \\
\text { article }\end{array}$ & $\begin{array}{l}\text { Currently, more randomized, controlled, multicenter clinical trials are needed to } \\
\text { find the optimal conditions for MSC therapy. }\end{array}$ \\
\hline 11. & $\begin{array}{l}\text { Agnes Arthur, a, b, } \\
\text { c Grigori Rychkov, } \\
\text { d et al. (2008) }\end{array}$ & English & $\begin{array}{l}\text { Laboratory } \\
\text { study }\end{array}$ & $\begin{array}{l}\text { Studies suggest that DPSCs are responsive to the surrounding microenvironment, } \\
\text { surviving, migrating, and differentiating accordingly into the appropriate cell } \\
\text { types within the avian host neural tissue. }\end{array}$ \\
\hline 12. & $\begin{array}{l}\text { Maryam Raoof, } \\
\text { Mohammad Mehdi } \\
\text { Yaghoobi, et al. }\end{array}$ & English & $\begin{array}{l}\text { Laboratory } \\
\text { study }\end{array}$ & $\begin{array}{l}\text { This study proposes a new method with high efficacy to obtain dental pulp stem } \\
\text { cells in a short time. }\end{array}$ \\
\hline
\end{tabular}

(2014)

Daniele Lindemann

Sefanie B. Werle

Daniela Steffens

13. Franklin Garcia- English

Godoy Patricia

Pranke Luciano

Casagrande. (2014)

14. Lin SL, Chang WJ, English
et al. (2015)

Laboratory study

Isolation success rate was $61 \%$ and $30 \%$ for non-cryopreserved and cryopreserved Laboratory groups respectively. There were no statistical differences between the groups for study the tested surface markers. The cells in both groups were capable of differentiating into three mesenchymal lineages.

Silvia Gioventu,

15. Gabriella Andriolo, English et al. (2012)

Laboratory study
SMF exposure improved DMSO-free cryopreservation. This phenomenon may be due to the improvement of membrane stability for resisting damage caused by ice crystals during the freezing procedure.

DPSC isolated from laser pierced cryopreserved teeth show mesenchymal stem cells morphology, immunophenotype, viability and proliferation rate similar to those of cells isolated from fresh, non cryopreserved teeth, whereas significant loss of cell viability and proliferation rate was shown by cells isolated from teeth cryopreserved without laser piercing. These data support the use of this method for prospective whole tooth banking. 


\section{Continued}

Ferro F, Spelat R,

16. Baheney CS. (2014)

English

Laboratory study

Rizwan Abdul

17. Rasheed Shaikh. English (2013)

Gary J. Doherty and

18. Harvey $\mathrm{T}$. McMahon. (2008) English

Review of article

George T.-J. Huang

19. Front Biosci. (2011)

English

Ana Angelova

20. Volponi, Yvonne Pang, et al. (2010)

English

Kylie M Ellis,

21. David C O’Carroll, English et al. (2014)

KOICHIRO

2. IOHARA, LI ZHENG, et al. English (2008)

Ishkitiev $\mathrm{N}$,

23. Yaegaki K, Imai T, English et al. (2012)

24. Patil R, Kumar BM, et al. (2014)

English

Chen YK, Huang

25. AH, et al. (2013)

Review of

article

Review of article

Laboratory study
DPSCs represent a rapidly proliferating cell population that readily differentiates into the osteoblastic, neuronal, myocytic, and hepatocytic lineages. This

multilineage capacity of these DPSCs suggests that they may have a more broad therapeutic application than lineage-restricted adult stem cell populations such as mesenchymal stem cells.

It might be possible to create an entire tooth to replace missing teeth. Now it is so clear that stem cells and tissue engineering can definitely give rise to a new branch

"Regenerative Dentistry" by giving alternatives to root canal treatment (RCT) and dental implants. On the other hand, it is equally true that the actual conditions to create the entire tooth and tooth tissue in order to use it clinically are not completely understood.

Highlight key molecular and physical variables that must be considered in order to mechanistically dissect events associated with changes in plasma membrane morphology. These considerations are integrated into the context of cell migration, filopodia formation, and clathrin-mediated endocytosis to show how a holistic view of the plasma membrane-cytoskeleton interface can allow for the appropriate interpretation of experimental findings and provide novel mechanistic insight into these important cellular events.

Regeneration of lost pulp and dentin tissues can reverse the deteriorated tooth, which is better than aggressive procedures that cause tooth structure loss. Dental stem cell-based approaches show capabilities of de novo regenerating pulp and new dentin.

Teeth are a viable source of adult mesenchymal stem cells for a wide range of Review of clinical applications. Ultimately, the use of these dental stem cells over other Review of sources of mesenchymal stem cells for therapeutic use will not only depend on ease of use and accessibility, but also on the efficiency and quality of repair in relation to cost.

mDPSC developed a neuronal morphology and high expression of neural markers nestin, $\beta$ III-tubulin and GFAP. NeurofilamentM and S100 were found in lower abundance. Differentiated cells also expressed protein markers for cholinergic, GABAergic and glutaminergicneurons, indicating a mixture of central and peripheral nervous system cell types. Intracellular electrophysiological analysis revealed the presence of voltage-gated L-type $\mathrm{Ca}^{2+}$ channels in a majority of cells with neuronal morphology.

Dental pulp-derived CD31; CD146 subfraction of SP cells is vasculogenic, and may Animal induce vasculogenesis in vivo in the amputated pulp model. We are aware of the study potential clinical utility to ameliorate ischemic disease and pulp regeneration in the cell therapy for endodontics and operative dentistry.

Cell cultures demonstrated a number of cells positive for all tested hepatic markers after differentiation, i.e. albumin-positive cells were almost $90 \%$ of differentiated

Laboratory deciduous pulp cells. The concentration of urea in the media increased significantly study after differentiation. Significant amount of cytoplasmic glycogen storage was found in the cells.

Antibodies raised against recombinant proteins were not much successful by in vivo Laboratory neutralization experiments [9] indicating uniqueness of the current study which has study documented successfully the existence of both neutralizing and non-neutralizing epitopes to MAbs raised against WSSV proteins isolated and purified from naturally infected shrimp samples collected from WSD outbreak ponds.

Review of hDPSCs from cryopreserved dental pulp tissues of vital extracted teeth with disease article could possess potential hepatic differentiation. 